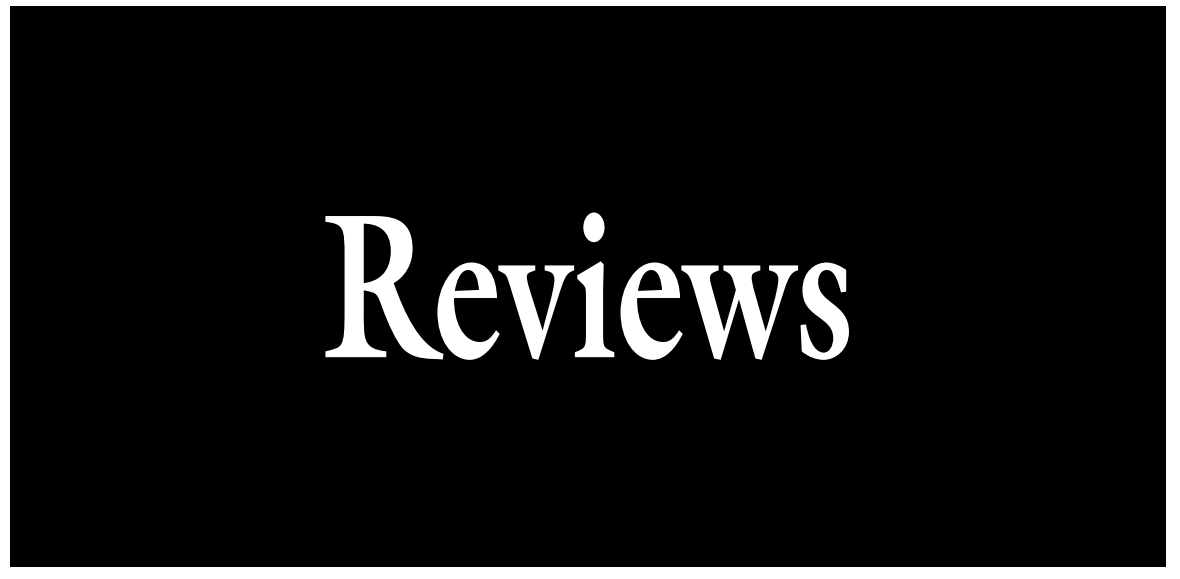

\title{
Commercial Amendments for Sand-based Root Zones: Review and Interpretation
}

\author{
Edward L. McCoy ${ }^{1}$
}

AdDITIONAL INDEX wORDs. biosolids compost, calcined clay, clinoptilolite zeolite, diatomaceous earth, reed-sedge peat, sphagnum peat

SUMMARY. Amendments used in sand-based root zones are typically native peats, composts, or inorganic materials of diverse mineralogy. Literature-based guidelines for amendment inclusion include root zone capillary porosity (CP) values exceeding $0.2 \mathrm{~m}^{3} \cdot \mathrm{m}^{-3}$ or soil surface water contents exceeding $0.1 \mathrm{~m}^{3} \cdot \mathrm{m}^{-3}$. It is also suggested that the cation exchange capacity (CEC) need not exceed $4 \mathrm{cmol}_{\mathrm{c}} \cdot \mathrm{kg}^{-1}$. Summarizing published data, native peat added to a U.S. Golf Association (USGA) guideline sand yielding organic matter $(O M)$ content values of $\approx 15 \mathrm{~g} \cdot \mathrm{kg}^{-1}$ would typically yield benchmark values of $\mathrm{CP}=0.2 \mathrm{~m}^{3} \cdot \mathrm{m}^{-3}$, surface water content $=0.1 \mathrm{~m}^{3} \cdot \mathrm{m}^{-3}$, and CEC values between 3 and $4 \mathrm{cmol}_{\mathrm{c}} \cdot \mathrm{kg}^{-1}$. This $\mathrm{OM}$ content is roughly equivalent to $15 \%$ by volume of a fibric sphagnum or $7.5 \%$ by volume of a hemic reed-sedge. By comparison $15 \%$ by volume of an inorganic amendment would likely result in CP and surface water content values less than the benchmark values, and CEC values between 1.5 and $4 \mathrm{cmol}_{\mathrm{c}} \cdot \mathrm{kg}^{-1}$. However, the CP benchmark measured at $30 \mathrm{~cm}$ of soil water suction should be re-evaluated because it may bias against the use of biosolids compost and inorganic amendments that reduce the thickness of the capillary fringe and create a broader pore size distribution. Also a weak relationship has been observed between longer-term turfgrass quality and $30-\mathrm{cm} C P$ values. Measurement of $C P$ at $40-\mathrm{cm}$ suction would be a better indication of water retention in sand-based root zones for all amendment types. Lastly, inorganic amendments produce a drier root zone that may be preferred for both playability and long-term agronomic concerns.

$\mathrm{R}$ oot zone amendments are typically organic materials or inorganic materials of diverse mineralogy that when added to sand at modest rates of $5 \%$ to $20 \%$ by volume are capable of substantially and permanently altering the physical and chemical properties of the root zone. There are a variety of reasons why specific amendments are selected and the choice of amendment should be associated with a specific reason.

$\overline{\text { School of Environment and Natural Resources, Ohio }}$ Agricultural Research and Development Center, Ohio State University, 1680 Madison Avenue, Wooster, $\mathrm{OH} 44691$

${ }^{1}$ Corresponding author. E-mail: mccoy.13@osu.edu.
Amendments are included in a sand-based root zone to increase water and nutrient retention. By increasing the water retention of unamended sand the intent is to avoid the early onset of drought between routine irrigation applications; and by increasing the nutrient retention the intent is to avoid the onset of nutrient stress between routine fertilizer applications. Amendments can also mitigate environmental concerns of excess water drainage and nutrient leaching from sand-based root zones. Guidelines have been proposed for the needed magnitude of water and nutrient retention within root zones. Thus, it has been suggested that the CP measured at $30-\mathrm{cm}$ suction, using American Society for Testing and Materials (ASTM) F 1815 protocols should exceed $0.2 \mathrm{~m}^{3} \cdot \mathrm{m}^{-3}$ (Murphy et al., 2001), or alternatively that the surface 3 -inch water content at $24 \mathrm{~h}$ of drainage should exceed $0.1 \mathrm{~m}^{3} \cdot \mathrm{m}^{-3}$ (Carlson et al., 1998). In both cases, these minimums were offered as requirements to achieve adequate turfgrass establishment from seed. Also it has been suggested that the CEC of a root zone need not exceed $\approx 4 \mathrm{cmol}_{\mathrm{c}} \cdot \mathrm{kg}^{-1}$ to provide adequate nutrient retention (Carrow et al., 2001).

Root zone response to amendments is generally influenced by texture, uniformity, and the amount of silt and clay of the amended sand (Davis et al., 1970; Waddington et al., 1974). Thus, fine- to medium-textured sands exhibit a lesser response, particularly with regard to water retention, to added amendments than do mediumto coarse-textured sands. This is also generally true when comparing less uniform sand (e.g., having a wide range of particle sizes) with more uniform sand. A lesser response to amendments is also observed with sands containing appreciable silt and clay contents. Further, an amendment rate effect is observed with most sands where increasing amendment amounts lead to greater water and nutrient retention. But there is a subtle difference in the way nutrient and water retention increase at greater rates of incorporation. In the case of nutrient retention expressed as the CEC of the

\begin{tabular}{llll}
\hline $\begin{array}{l}\text { Units } \\
\begin{array}{l}\text { To convert U.S. to SI, } \\
\text { multiply by }\end{array}\end{array}$ & U.S. unit & SI unit & $\begin{array}{l}\text { To convert SI to U.S., } \\
\text { multiply by }\end{array}$ \\
\hline 10 & $\%$ & $\mathrm{~g} \cdot \mathrm{kg}^{-1}$ & 0.1 \\
0.3048 & $\mathrm{ft}$ & $\mathrm{m}$ & 3.2808 \\
0.0283 & $\mathrm{ft}^{3}$ & $\mathrm{~m}^{3}$ & 35.3147 \\
2.54 & inch $(\mathrm{es})$ & $\mathrm{cm}$ & 0.3937 \\
25.4 & inch $(\mathrm{es})$ & $\mathrm{mm}$ & 0.0394 \\
1 & meq $/ 100 \mathrm{~g}$ & $\mathrm{cmol} \cdot \mathrm{kg}^{-1}$ & 1 \\
1 & mmho $/ \mathrm{cm}$ & $\mathrm{dS} \cdot \mathrm{m}^{-1}$ & 1
\end{tabular}

Hortlechnology · December 2013 23(6) 
root zone, amendments that possess CEC yield a linear increase in CEC with incrementally increasing rates of incorporation. However, increasing water retention at successively greater incorporation rates shows diminishing returns. That is, incremental amendment additions have progressively smaller effects. Consequently, there is a practical upper limit in the ability of a particular amendment to increase the water retention of sand (McCoy, 1998).

Carlson et al. (1998) state that increasing root zone water content is the most important reason for using an amendment. Yet there has been a recent trend to consider other goals for incorporating amendments in sandbased root zones, with a focus not so much on establishment from seed, but on longer-term, agronomic and playability performance. This recent trend has led to formulating root zones that yield drier surface-layer conditions, motivated by improved playability (where drier soil conditions generally result in firmer and smoother surfaces) and by the potential to reduced disease problems associated with a drier surface. An obvious trade-off occurs because drier root zones need more frequent irrigation, contributing to greater water use, and more precise irrigation application. However, this is not considered to be much of a concern because the total putting green area of a golf course is rather small and greater water use on greens should not substantially increase overall irrigation costs. Further, the need for more precise irrigation has been met by newer irrigation technologies and the use of root zone moisture sensors for irrigation scheduling.

Sand texture, uniformity, and the amount of silt and clay have a profound effect on the hydraulic properties of sand-based root zones (Bigelow et al., 2004; Davis et al., 1970; Waddington et al., 1974; Zhang and Baker, 1999). More subtle but also important are the effects of amendments that may be added to a sand to create a root zone. Thus, the purpose of this article is to summarize recent reports on the water and nutrient retention properties of sand-based root zones containing the most commonly used and commercially available amendments. The focus of much of the studies is on new construction of a USGA putting

Table 1. The organic matter $(\mathrm{OM})$, fiber content, electrical conductivity $\left(\mathrm{EC}_{\mathrm{e}}\right)$, cation exchange capacity (CEC), and pH of some commercially available organic amendments. OM was determined using ASTM D 2974 Method C, loss on ignition at $440{ }^{\circ} \mathrm{C}\left(824.0^{\circ} \mathrm{F}\right)$. Fiber content defined as the mass percent retained on a 100 -mesh $[0.15 \mathrm{~mm}(0.006 \mathrm{inch})]$ sieve was determined following McCoy (1992). EC was determined on a saturated paste extract following U.S. Department of Agriculture (1954). CEC was determined using the displacement after acid washing method of Thorpe (1973). $\mathrm{pH}$ was determined using ASTM D 2976 in distilled water.

\begin{tabular}{|c|c|c|c|c|c|}
\hline Material & $\frac{\mathrm{OM}}{\left(\mathrm{g} \cdot \mathrm{kg}^{-1}\right)^{\mathrm{z}}}$ & $\frac{\text { Fiber }}{(\% \mathrm{wt})}$ & $\frac{\mathrm{EC}_{\mathrm{e}}}{\left(\mathrm{dS} \cdot \mathrm{m}^{-1}\right)^{\mathrm{z}}}$ & $\frac{\mathrm{CEC}}{\left(\mathrm{cmol}_{\mathrm{c}} \cdot \mathrm{kg}^{-1}\right)^{\mathrm{z}}}$ & $\mathrm{pH}$ \\
\hline \multicolumn{6}{|l|}{ Native peats } \\
\hline Light sphagnum & 969 & 71.8 & 0.3 & 163 & 3.9 \\
\hline Dark sphagnum & 883 & 43.8 & 0.5 & 151 & 4.3 \\
\hline Reed-sedge 1 & 863 & 47.3 & $\mathrm{nd}^{\mathrm{y}}$ & 178 & 6.5 \\
\hline Reed-sedge 2 & 694 & 34.2 & 0.3 & 118 & 5.1 \\
\hline Peat humus & 346 & 6.9 & nd & 86 & 4.8 \\
\hline \multicolumn{6}{|l|}{ Composts } \\
\hline Yard waste compost & 398 & 18.1 & 1.1 & 77 & 8.9 \\
\hline Leaf compost & 540 & 26.1 & 1.5 & 112 & 8.6 \\
\hline Biosolids compost & 683 & 50.5 & 4.4 & 52 & 8.6 \\
\hline Mushroom compost & 551 & 23.2 & 8.5 & 86 & 8.8 \\
\hline
\end{tabular}

${ }^{\mathrm{z}} \mathrm{l} \mathrm{g} \cdot \mathrm{kg}^{-1}=0.1 \%, \mathrm{l} \mathrm{dS} \cdot \mathrm{m}^{-1}=1 \mathrm{mmho} / \mathrm{cm}, 1 \mathrm{cmol}_{\mathrm{c}} \cdot \mathrm{kg}^{-1}=1 \mathrm{meq} / 100 \mathrm{~g}$.

Not determined.

green root zones. Thus, the sand into which amendments are incorporated generally conformed to USGA particle size guidelines and hereafter will be referred to as USGA-guideline sand. However, it is important to note that USGA-guideline sands are not all identical but rather span a reasonably narrow range of particle size distributions.

\section{Amendment properties}

Organic amendments. The most common organic amendments are either native peats or composts. Organic matter content is the most important characteristic of an organic amendment and is typically determined as the weight loss of a sample after ashing in a muffle furnace. The standard classification of native peats (ASTM D 2607) specifies that the term peat be reserved for organic materials of geologic origin (excluding coal) having an OM content exceeding $750 \mathrm{~g} \cdot \mathrm{kg}^{-1}$. This value was chosen because peats marketed as organic amendments should preferably contain a large mass fraction of $\mathrm{OM}$. Yet some organic amendments referred to as peats, such as reed-sedge 2 and peat humus (Table 1 ), have OM contents smaller than this limit. Interestingly, composts (particularly biosolids compost) have been successfully used in sand-based root zones when the compost material has OM content as low as $600 \mathrm{~g} \cdot \mathrm{kg}^{-1}$ and compost OM contents rarely exceed
$700 \mathrm{~g} \cdot \mathrm{kg}^{-1}$. So, the defined OM limit for native peats may not apply for composts.

Fiber content is defined as the percent of the organic material retained on a $0.15-\mathrm{mm}$ (100-mesh) sieve and reflects the visibly observed, fibrous nature of an organic amendment. A classification scheme based on fiber content (ASTM D 4427) defines peats with greater than $67 \%$ fiber content as fibric, peats with $33 \%$ to $67 \%$ fiber content as hemic, and peats with less than 33\% fiber content as sapric. Thus, only the light sphagnum sample of Table 1 is classified as being fibric and both of the reed-sedge peats samples are classified as being hemic. Whereas OM content is commonly measured in research with organic amendments, fiber content is rarely measured. But because there is typically a close correspondence between OM content and fiber content (Table 1) inferences can be drawn as to the fibrous nature of an organic amendment based on OM content alone. This is particularly true for native peat sources where materials with larger OM contents are more fibrous, and native peats with OM contents exceeding $900 \mathrm{~g} \cdot \mathrm{kg}^{-1}$ are often considered superior for sandbased root zones because of the fibric nature of these materials.

Fiber content also has an effect on the mass of OM in a sand blend when formulated on a volumetric basis. In this case, equal volumes of a 
more fibrous organic material yield a smaller mass-based OM content than a less fibrous organic material. This can be seen from measurements of $\mathrm{OM}$ in sand mixes where $10 \%$ volume addition of more fibrous sphagnum peat yielded from 4.4 to $16 \mathrm{~g} \cdot \mathrm{kg}^{-1}$ $\mathrm{OM}$ and $10 \%$ volume addition of less fibrous reed-sedge yielded from 7.3 to $36 \mathrm{~g} \cdot \mathrm{kg}^{-1} \mathrm{OM}$ (Bigelow et al., 2004; McCoy, 1992; McCoy et al., 2007; Murphy et al., 2004, 2005). Within these ranges, greater OM contents were generally observed by McCoy and smaller OM contents were observed by Murphy. Consequently there is an $\approx 2$-fold increase in OM by weight for reed-sedge as compared with sphagnum mixtures. Or, said another way, a 90:10 volume ratio sand:reed-sedge blend can have a similar OM content as a 80:20 sand:sphagnum blend. This is simply because the mass per unit volume, or bulk density, of an organic amendment is less for a more fibrous than a less fibrous organic material (Taylor and Blake, 1984). Also notice that for a given organic amendment, the mass-based OM content from these various studies spans a rather wide range. This is likely because different ashing temperatures were used among the varying studies or because varying degrees of fluffing of an organic material may occur before mixing. Finally, when incorporated into sand, $10 \%$ additions of compost yielded 8.1 to $23 \mathrm{~g} \cdot \mathrm{kg}^{-1} \mathrm{OM}$ (McCoy, 1992; Murphy et al., 2004), greater than the same volume of sphagnum.

The CEC reflects the nutrient retention properties of a soil or amendment. When considering native peats, larger CEC values are observed for the organic amendments having the greater OM content (Table 1 ). However, with composts such a relationship is not so clear and CEC values appear to be generally independent of OM content. For example, the biosolids compost of Table 1 contained $680 \mathrm{~g} \cdot \mathrm{kg}^{-1} \mathrm{OM}$ but a CEC value of only $52 \mathrm{cmol}_{\mathrm{c}} \cdot \mathrm{kg}^{-1}$, the smallest of all compost samples. Since organic materials are added to root zones for their nutrient retention properties, it is desirable to select an organic amendment having a larger CEC. This would seemingly argue against the use of composts in sand-based root zones. However, the less weathered compost materials also contain a variety of macro- and micronutrients that can be beneficial in turfgrass establishment and long-term maintenance.

Many native peats tend to have low $\mathrm{pH}$ values ranging from 3.9 to 6.5 (Table 1), which can serve to reduce the final $\mathrm{pH}$ of a root zone mix depending on the incorporation rate. By comparison, composts tend to have higher $\mathrm{pH}$ values ranging from 8.6 to 8.9. Provided the blended root zone $\mathrm{pH}$ values are not extreme, this characteristic is not viewed as terribly important because sand-based root zones are generally poorly buffered. Soluble salt levels greater than $4.0 \mathrm{dS} \cdot \mathrm{m}^{-1}$ are often injurious to plants. Some compost materials such as biosolids and mushroom compost contain excessive soluble salt levels (Table 1). However, soluble salts are diluted upon mixing with sand and are readily leached from the root zone with frequent irrigation during turfgrass establishment. Thus, soluble salt levels within the organic amendment are not of primary concern and should not exclude amendment use.

Other organic amendments include water-absorbing polymers, paper waste, and coconut coir. Waterabsorbing polymers are a problem in that they swell to mechanically weak bodies within the soil. The swelling can cause the ground to heave, and subsequent foot and vehicle traffic result in a very uneven surface. From my limited experience, paper waste has a very low fiber content and limited information exists on the use of coconut coir in sand-based root zones (except Cook and Baker, 1998). Although organic in nature, seaweed and humic acids are not exactly soil amendments in terms of playing the traditional roles of substantially modifying soil physical and chemical properties. This is because the added amounts are typically small and in the case of seaweed, which decomposes rapidly, transient. These materials are better viewed as growth supplements, along with liquid-solution-applied extracts, that may serve a role in metal chelation and as plant hormone analogues. One organic material that may have potential is biochar, formed from the pyrolysis of biomass. A recent paper (Brockhoff et al., 2010) reported that biochar amendment increased water retention and had an effect on nitrogen nutrition.

INORGANIC AMENDMENTS. There are three major classes of inorganic amendments, including porous ceramics or calcined clay (CC) products such as Profile (Profile Products, Buffalo Grove, IL), clinoptilolite zeolite (CZ) products such as Ecolite (Western Organics, Tempe, AZ), and diatomaceous earth (DE) products such as Axis (EnviroTech Soil Solutions, Oregon City, OR). Inorganic amendments come in various particle sizes and particle uniformity (Table 2) with CC having $98 \%$ by weight of particles in the medium and coarse size classes, $\mathrm{CZ}$ having $75 \%$ by weight of particles in the medium and coarse size classes with a significant portion in the fine and smaller classes, and DE having $69 \%$ by weight of the particles in the medium and coarse size classes with most of the remainder in the very coarse class. Thus CC is very uniform and most closely matches the USGArecommended particle size distribution of a root zone (Table 2).

These amendments are sand-sized, roughly spherical mineral particles that, unlike sand have considerable internal porosity. For a packed sample of the amendments by themselves, $23 \%$ to

Table 2. Particle size distributions of commercially available inorganic amendments and U.S. Golf Association (USGA)-recommended particle size distribution for a root zone mix. Data for diatomaceous earth (DE) amendment are taken from Table 1 of McCoy and Stehouwer (1998). Data for calcined clay (CC) and clinoptilolite zeolite (CZ) amendments are taken from Table 1 of Murphy et al. (2005).

\begin{tabular}{|c|c|c|c|c|c|c|c|}
\hline \multirow[b]{3}{*}{ Material } & \multicolumn{7}{|c|}{ Mesh opening $(\mathrm{mm})^{\mathrm{z}}$} \\
\hline & 2 & 1 & 0.5 & 0.25 & 0.15 & 0.05 & $<0.05$ \\
\hline & \multicolumn{7}{|c|}{ 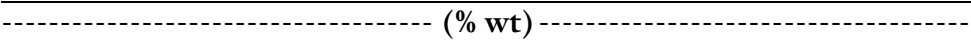 } \\
\hline $\mathrm{CC}$ & 0 & 0.2 & 65.6 & 32.3 & 0.9 & 0.4 & 0.6 \\
\hline $\mathrm{CZ}$ & 0 & 16.3 & 52.3 & 22.9 & 3.1 & 1.4 & 4.0 \\
\hline $\mathrm{DE}$ & 0 & 29.5 & 51.3 & 17.9 & 0.6 & 0.6 & 0.1 \\
\hline USGA $^{y}$ & \multicolumn{2}{|c|}{$\leq 10(\leq 3$ gravel $)$} & \multicolumn{2}{|c|}{60 minimum } & $\leq 20$ & $\leq 5$ & $\leq 8$ \\
\hline
\end{tabular}

${ }^{2} 1 \mathrm{~mm}=0.0394$ inch.

${ }^{y}$ Also, very fine sand, silt, and clay combined should be $\leq 10 \%$ and clay should be $\leq 3 \%$. 
$36 \%$ of the total volume consists of pores with diameters $<0.08 \mathrm{~mm}$, which are considered to be internal pores (Bigelow et al., 2004). Twenty percent by volume mixes with sand contain $8 \%$ to $12 \%$ of the total volume consisting of pores with diameters $<0.08 \mathrm{~mm}$. These internal pores, because of their smaller size and because they are not connected one to another, contribute to water retention of the root zone. The ranking of amendment internal porosity follows the order $\mathrm{CZ}<\mathrm{CC}=\mathrm{DE}$ (Bigelow et al., 2004; Githinji et al., 2006). Inorganic amendments also vary by class in their $\mathrm{CEC}$ values with $\mathrm{CZ}$ ranging from 100 to $230 \mathrm{cmol}_{\mathrm{c}} \cdot \mathrm{kg}^{-1}$, CC up to $33 \mathrm{cmol}_{\mathrm{c}} \cdot \mathrm{kg}^{-1}$, and DE from 1.2 for calcined DE to $27 \mathrm{cmol}_{\mathrm{c}} \cdot \mathrm{kg}^{-1}$ for noncalcined DE (Carrow et al., 2001).

\section{Amendment effects on root zone hydraulic properties}

Organic amendments. The physical properties of sand-based root zones that are often used to characterize its hydraulic performance in the field are the CP, air-filled porosity, and saturated hydraulic conductivity (Ks). Because these properties of an organic amendment alone are of little value in predicting root zone behavior, physical properties are determined for a given sand-amendment mixture.

Literature measurement of $\mathrm{CP}$ have used soil water suction values of $30 \mathrm{~cm}, 40 \mathrm{~cm}$, or both, and the resultant $C P$ value will depend on the suction at which it was measured. Amending a USGA-guideline sand with an organic amendment generally results in greater CP values determined at $40-\mathrm{cm}$ soil water suction. Sphagnum peat incorporation rates from $10 \%$ to $20 \%$ by volume increased CP values from 0.01 to $0.11 \mathrm{~m}^{3} \cdot \mathrm{m}^{-3}$ (Bigelow et al., 2001b; McCoy, 1992; McCoy et al., 2007; Waltz et al., 2003 ) with greater increases at larger incorporation rates. Results with a biosolids compost were similar to sphagnum, and equal volumes of reedsedge had $40-\mathrm{cm} \mathrm{CP}$ values $\approx 2$-fold greater than sphagnum (McCoy, 1992). When defining CP at $30-\mathrm{cm}$ suction, $10 \%$ amendment of sphagnum peat to USGA-guideline sand increased $\mathrm{CP}$ values by 0.02 to $0.07 \mathrm{~m}^{3} \cdot \mathrm{m}^{-3}$ (McCoy, 1992; McCoy et al., 2007; Murphy et al., 2005). However, for composts $30-\mathrm{cm}$ CP results differed from the general organic amendment trend with values either less than unamended USGA-guideline sand (Murphy et al., 2004) or decreased with increasing incorporation rates (McCoy, 1992).

In terms of equaling or exceeding a benchmark $\mathrm{CP}$ value of 0.2 $\mathrm{m}^{3} \cdot \mathrm{m}^{-3}, \mathrm{McCoy}(1992)$ specified that this would require root zone OM contents of at least $35 \mathrm{~g} \cdot \mathrm{kg}^{-1}$. This weight fraction of OM corresponded to incorporation rates of $20 \%$ by volume for sphagnum peat and a biosolids compost, and $10 \%$ by volume for reed-sedge peat. Note that this volume ratio specification was made for CP measured at $40-\mathrm{cm}$ suction, which would have smaller values compared with the current $30-\mathrm{cm}$ measurement. When defining capillarity porosity at $30-\mathrm{cm}$ suction, unamended USGAguideline sand as well as sand amended with $10 \%$ by volume of sphagnum, reed-sedge, and compost all exceeded $30-\mathrm{cm} \mathrm{CP}$ values of $0.2 \mathrm{~m}^{3} \cdot \mathrm{m}^{-3}(\mathrm{McCoy}$ 1992; Murphy et al., 2005). Further, two sands, either unamended or amended with $10 \%$ sphagnum, failed to achieve CP values of $0.2 \mathrm{~m}^{3} \cdot \mathrm{m}^{-3}$ (McCoy et al., 2007). Comparing sphagnum peat to quality composts, $10 \%$ volume compost mixes yielded equivalent if slightly lower CP values (McCoy, 1992; Murphy et al., 2004). Finally, findings from an American Association for Laboratory Accreditation (A2LA)-certified testing laboratory using ASTM F1815 methods concluded that if a USGA-guideline sand is approaching the upper limit of $200 \mathrm{~g} \cdot \mathrm{kg}^{-1}$ for the combined fine and very fine sand category then this $C P$ benchmark can be achieved with 10\% sphagnum although in most cases it required a minimum of $20 \%$ by volume sphagnum to achieve a $30-\mathrm{cm}$ CP value of $0.2 \mathrm{~m}^{3} \cdot \mathrm{m}^{-3}(\mathrm{~N}$. Hummel, personal communication). So although it is difficult to surmise a precise rule of organic amendment incorporation required to achieve the benchmark $\mathrm{CP}$ value, it generally appears that $10 \%$ to $20 \%$ by volume of sphagnum peat or quality compost and $5 \%$ to $10 \%$ of a reed-sedge peat is appropriate for most root zone sands.

Organic amendments added to USGA-guideline sands generally reduce both air-filled porosity and Ks values. Differences in this response among various organic amendments seem to be related to the fiber content, where less fibrous amendments yielded a greater reduction than more fibrous amendments. Thus, at equal volume mixing ratios, reed-sedge peat produced somewhat smaller $30-\mathrm{cm}$ air-filled porosity and Ks values than sphagnum peat (McCoy, 1992; Muehlbach et al., 2007; Murphy et al., 2005). Higher OM content and more fibrous composts yielded similar air-filled porosity and Ks values to that of a sphagnum at equal volume mixing ratios (McCoy, 1992; Murphy et al., 2004). An exception to the general rule has been noted for larger incorporation rates of sphagnum (Muehlbach et al., 2007) and biosolids compost (McCoy, 1992) where Ks values were greater than those of unamended USGA-guideline sand.

How can fiber content affect the permeability of a sand:peat mix? Consider that packing of spherical particles yields a maximum pore diameter $41.4 \%$ of the particle diameter itself (McGeary, 1961). Then for medium sand having a midparticle diameter $\left(\mathrm{D}_{50}\right)$ value of $0.375 \mathrm{~mm}$, its maximum pore diameter will be $\approx 0.15 \mathrm{~mm}$. Blending this sand with a peat having a larger fiber content would result in a greater proportion of the fibers that could not fit within this maximum pore diameter. These fibers would span between individual sand particles, reducing the degree of sand packing, and increasing the permeability relative to that of the sand alone. A peat with smaller fiber content would have a greater proportion of fibers that could easily fit within $0.15-\mathrm{mm}$ pores and would serve to occlude the pores in the mixture. Consequently, the permeability or Ks value of a root zone mixture may become sufficiently small to impede adequate drainage. For this reason fibric organic amendments, with fiber contents exceeding $67 \%$, would be considered the higherquality material. A greater fiber content organic material could be added at sufficient rates to increase CP but not severely impact drainage.

INORGANIC AMENDMENTS. Like organic amendments, inorganic amendments consistently increased $\mathrm{CP}$ values determined at $40-\mathrm{cm}$ suction relative to unamended medium or USGAguideline sand (Bigelow et al., 2001b, 2004; McCoy and Stehouwer, 1998; Waltz et al., 2003). Calcined clay incorporation rates from $10 \%$ to $20 \%$ volume increased $\mathrm{CP}$ values from 0.01 
to $0.06 \mathrm{~m}^{3} \cdot \mathrm{m}^{-3}, \mathrm{CZ}$ incorporation rates from $10 \%$ to $20 \%$ volume increased CP values from 0.01 to $0.03 \mathrm{~m}^{3} \cdot \mathrm{m}^{-3}$, and $\mathrm{DE}$ incorporation rates from $10 \%$ to $20 \%$ volume increased $\mathrm{CP}$ values from 0.02 to $0.07 \mathrm{~m}^{3} \cdot \mathrm{m}^{-3}$. Greater increases were observed at the larger incorporation rates. Yet at the larger incorporation rates inorganic amendments had smaller $40-\mathrm{cm}$ CP values than comparable rates of sphagnum peat (Bigelow et al., 2004; Waltz et al., 2003). The apparent order of inorganic amendments effects on $40-\mathrm{cm}$ $\mathrm{CP}$ values was $\mathrm{CZ}<\mathrm{CC}=\mathrm{DE}$.

Alternatively, when defining $\mathrm{CP}$ at $30-\mathrm{cm}$ suction, inorganic amendment incorporation either increased or decreased CP values relative to unamended, USGA-guideline sand (Bigelow et al., 200la; McCoy and Stehouwer, 1998; Murphy et al., $2004,2005)$. The range of CP values was from $0.03 \mathrm{~m}^{3} \cdot \mathrm{m}^{-3}$ less than unamended sand for both a $10 \%$ volume $\mathrm{CC}$ and $\mathrm{CZ}$ to $0.03 \mathrm{~m}^{3} \cdot \mathrm{m}^{-3}$ greater than unamended sand for $20 \%$ volumeextruded DE. Further, there was no consistent pattern across all studies for increasing CP values at increased incorporation rates.

Varying responses also occur when comparing root zone $\mathrm{CP}$ values to the $30-\mathrm{cm}$ CP benchmark. Thus, unamended USGA-guideline sand as well as sand amended with $10 \%$ or $20 \%$ by volume CC, CZ, and DE all exceeded the benchmark $\mathrm{CP}$ value of $0.2 \mathrm{~m}^{3} \cdot \mathrm{m}^{-3}$ (Murphy et al., 2004, 2005). Yet from Bigelow et al. (200la) only $20 \%$ volume DE among all classes of inorganic amendments exceeded this CP benchmark value. Further, $30-\mathrm{cm}$ CP data from two A2LA-certified laboratories averaged $0.14 \mathrm{~m}^{3} \cdot \mathrm{m}^{-3}$ $(n=18)$ for unamended sand and $0.175 \mathrm{~m}^{3} \cdot \mathrm{m}^{-3}(n=22)$ for $15 \%$ volume CC-amended root zone mixes. So it appears that although all inorganic amendments serve to increase water retention in sand-based root zones, their effects on $30-\mathrm{cm} C P$ values varied with regard to both exceeding that of unamended sand and achieving a benchmark CP value. This is similar to the response observed with compost.

Because inorganic amendments tend to have larger mean particle diameters than USGA-guideline sands, their addition to sand will increase the number of larger-diameter pores and thus increase air-filled porosity. Thus, $10 \%$ and $20 \%$ volume amendment rates of CC, DE, and CZ generally values by 0.05 to $0.1 \mathrm{~m}^{3} \cdot \mathrm{m}^{-3}$ (McCoy and Stehouwer, 1998; Murphy et al., $2004,2005)$. Yet compared with unamended USGA-guideline sand, 10\% volume DE and CZ (Murphy et al., 2004, 2005), 15\% volume DE (Waltz et al., 2003), and 20\% DE and CZ (Muehlbach et al., 2007) all reduced Ks values whereas similar rates of CC resulted in either significantly greater or equal Ks values. However, Bigelow et al. (200la) showed reduced Ks values for $20 \%$ volume amendment of all inorganic amendments compared with unamended sand having a narrow particle size distribution. Also, compared with equal volume addition rates of sphagnum peat, all inorganic amendments yielded equal (as in the case of DE and CZ in Murphy et al., 2004, 2005) or greater Ks values (Bigelow et al., 200la; Waltz et al., 2003). Further, $30-\mathrm{cm}$ air-filled porosity and Ks data from two A2LAcertified laboratories averaged 0.284 $\mathrm{m}^{3} \cdot \mathrm{m}^{-3}$ and 30 inches $/ \mathrm{h}(n=18)$, $0.294 \mathrm{~m}^{3} \cdot \mathrm{m}^{-3}$ and 37 inches $/ \mathrm{h}(n=$ 22), respectively, for $15 \%$ volume CC-amended root zone mixes.

\section{Amendment effects on the water retention curve}

Organic amendments. The water retention properties of a sandorganic amendment mixture can be increased $30-\mathrm{cm}$ air-filled porosity respectively, for unamended sand and

viewed in detail by constructing a water retention curve. Data from McCoy (1992) were used to plot water retention curves for unamended, USGA-guideline sand, and sand amended with $35 \mathrm{~g} \cdot \mathrm{kg}^{-1}$ sphagnum or reed-sedge peats (Fig. 1). It is recognized that $35 \mathrm{~g} \cdot \mathrm{kg}^{-1} \mathrm{OM}$ would represent an extreme organic amendment level, not characteristic of actual construction practices. This amendment level was chosen to highlight differences between the various organic sources.

In contrast to unamended sand, the sphagnum- and reed-sedge-amended sand curves are displaced upward, indicating increased total porosity and water retention. The reed-sedgeamended curve is also shifted to the right. This leads to the reed-sedge curve being a bit steeper in the region from 20 - to $40-\mathrm{cm}$ suction. Compared with unamended sand, therefore, reedsedge amendment yields smaller pore diameters and a narrowing of the pore size distribution (McCoy, 1992).

For soil water suction values greater than $\approx 80 \mathrm{~cm}$, water content of the reed-sedge peat exhibits a steady decline whereas the sphagnum curve is rather flat (Fig. 1). This would suggest that the less fibrous, reedsedge-amended root zone is capable of continued water release within this suction range whereas the more fibrous sphagnum is not; at least as interpreted by water retention measurements (McCoy, 1992). Thus, the overall

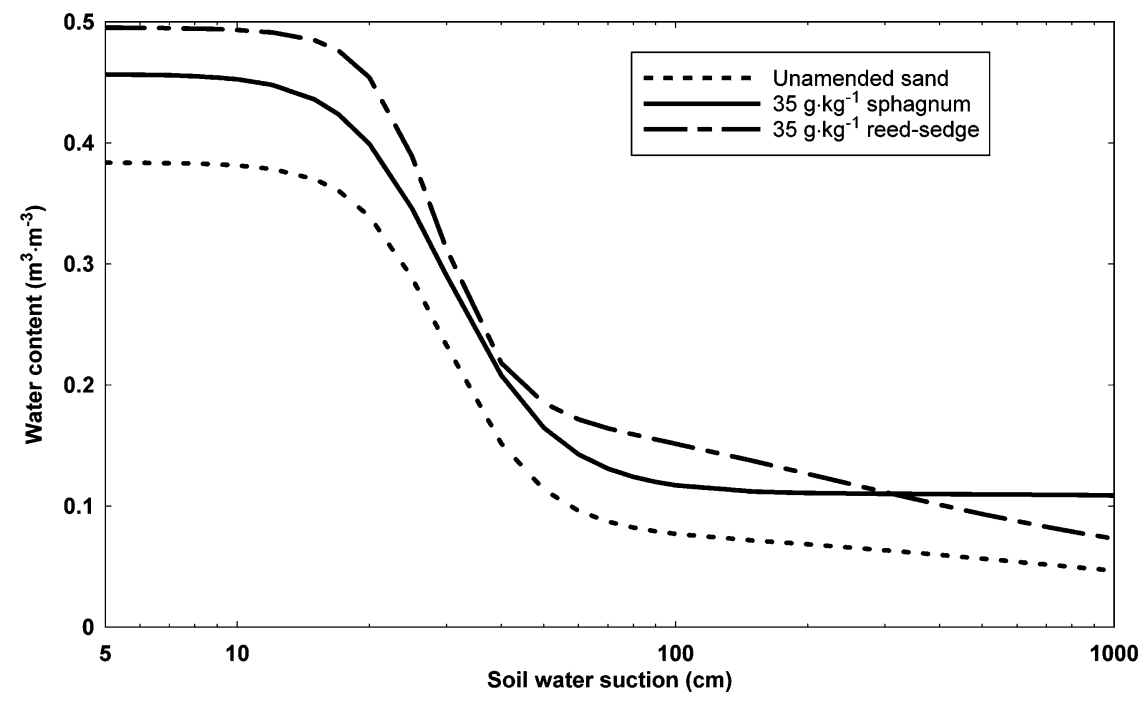

Fig. 1. Water retention curves for unamended U.S. Golf Association (USGA) guideline sand and the sand amended with $35 \mathrm{~g} \cdot \mathrm{kg}^{-1}(3.5 \%)$ sphagnum and reedsedge peat. The curves are drawn from equations presented in Table 3 of McCoy $(1992) ; 1 \mathrm{~cm}=0.3937 \mathrm{inch}, 1 \mathrm{~m}^{3} \cdot \mathrm{m}^{-3}=100 \%$. 
Table 3. Estimated capillary fringe thickness and pore uniformity index (maximum value of slope for the water retention curve) of root zones as influenced by sand texture, amendment, and amendment rate. For Taylor et al. (1997) the data are taken from the text and from their Fig. 1. For McCoy and Stehouwer (1998) the data are taken from their Table 5. For the other references, the capillary fringe thickness and the pore uniformity index are calculated from Eqs. [4a] and [3a], respectively, of McCoy and Stehouwer (1998). For Bigelow et al. (2004) data taken from their Fig. 3 are fit to the Van Genuchten (1980) water retention equation before analysis. Significance testing of root zones was possible only from data of McCoy and Stehouwer (1998) and McCoy et al. (2007). Otherwise, the water retention data of the referenced literature was pooled and confidence limits could not be calculated.

\begin{tabular}{|c|c|c|c|}
\hline Reference & Root zone ${ }^{z}$ & $\begin{array}{l}\text { Capillary fringe } \\
\text { thickness }(\mathrm{cm})^{\mathrm{y}}\end{array}$ & $\begin{array}{l}\text { Pore uniformity } \\
\text { index } \\
\left(\mathrm{m}^{3} \cdot \mathbf{m}^{-3} \cdot \mathbf{m}^{-1}\right)^{y}\end{array}$ \\
\hline \multicolumn{4}{|c|}{ McCoy (1992) } \\
\hline & USGA-guideline sand & 16.8 & 3.7 \\
\hline & Sand $+35 \mathrm{~g} \cdot \mathrm{kg}^{-1}$ sphagnum peat & 15.3 & 3.3 \\
\hline & Sand $+35 \mathrm{~g} \cdot \mathrm{kg}^{-1}$ reed-sedge peat & 18.5 & 5.0 \\
\hline & Sand $+35 \mathrm{~g} \cdot \mathrm{kg}^{-1}$ biosolids compost & 11.2 & 2.8 \\
\hline \multicolumn{4}{|c|}{ Taylor et al. (1997) } \\
\hline & Coarser USGA-guideline sand & 6 & $\mathrm{nd}^{\mathrm{x}}$ \\
\hline & $\begin{array}{l}\text { Coarser sand }+20 \% \text { by volume } \\
\text { sphagnum peat }\end{array}$ & 9 & nd \\
\hline & $\begin{array}{l}\text { Coarser sand }+20 \% \text { by volume } \\
\text { reed-sedge peat }\end{array}$ & 12 & nd \\
\hline & Finer non-USGA-guideline sand & 12 & nd \\
\hline & $\begin{array}{l}\text { Finer sand }+20 \% \text { by volume } \\
\text { sphagnum peat }\end{array}$ & 15 & nd \\
\hline & $\begin{array}{l}\text { Finer sand }+20 \% \text { by volume } \\
\text { reed-sedge peat }\end{array}$ & 18 & nd \\
\hline \multicolumn{4}{|c|}{ McCoy and Stehouwer (1998) } \\
\hline & Coarse sand & 2.1 & 10.9 \\
\hline & $\begin{array}{l}\text { Coarse sand }+28 \mathrm{~g} \cdot \mathrm{kg}^{-1} \text { sphagnum } \\
\text { peat }\end{array}$ & 6.8 & 4.2 \\
\hline & Coarse sand $+20 \%$ by volume CC & 1.7 & 11.7 \\
\hline & Coarse sand $+10 \%$ by volume $\mathrm{DE}$ & 5.5 & 9.1 \\
\hline & Medium sand & 17.0 & 4.5 \\
\hline & $\begin{array}{l}\text { Medium sand }+28 \mathrm{~g} \cdot \mathrm{kg}^{-1} \text { sphagnum } \\
\text { peat }\end{array}$ & 9.7 & 3.4 \\
\hline & Medium sand $+20 \%$ by volume CC & 10.6 & 5.4 \\
\hline & Medium sand $+10 \%$ by volume $\mathrm{DE}$ & 10.3 & 4.6 \\
\hline & $\operatorname{LSD}(0.05)^{\mathrm{w}}$ & 2.1 & 1.6 \\
\hline \multicolumn{4}{|c|}{ Bigelow et al. (2004) } \\
\hline & Medium sand & 13.0 & 5.2 \\
\hline & $\begin{array}{l}\text { Medium sand }+20 \% \text { by volume } \\
\text { sphagnum peat }\end{array}$ & 14.2 & 3.9 \\
\hline & Medium sand $+20 \%$ by volume CC & 11.8 & 4.6 \\
\hline & Medium sand $+20 \%$ by volume $\mathrm{DE}$ & 14.7 & 4.8 \\
\hline & Medium sand $+20 \%$ by volume $\mathrm{CZ}$ & 12.4 & 4.7 \\
\hline \multicolumn{4}{|c|}{ McCoy et al. (2007) } \\
\hline & Coarser USGA-guideline sand & 3.3 & 5.1 \\
\hline & $\begin{array}{l}\text { Coarser sand }+10 \% \text { by volume } \\
\text { sphagnum peat }\end{array}$ & 9.6 & 7.5 \\
\hline & Finer USGA-guideline sand & 7.4 & 3.7 \\
\hline & $\begin{array}{l}\text { Finer sand }+10 \% \text { by volume } \\
\text { sphagnum peat }\end{array}$ & 12.1 & 9.7 \\
\hline & $\operatorname{LSD}(0.05)$ & 1.0 & 0.8 \\
\hline
\end{tabular}

${ }^{\mathrm{z}} \mathrm{USGA}=\mathrm{U} . S$. Golf Association, $\mathrm{CC}=$ calcined clay, $\mathrm{DE}=$ diatomaceous earth, $\mathrm{CZ}=$ clinoptilolite zeolite; $1 \mathrm{~g} \cdot \mathrm{kg}^{-1}=$ $0.1 \%$.

${ }^{\mathrm{y}} \mathrm{l} \mathrm{cm}=0.3937 \mathrm{inch}, \mathrm{l} \mathrm{m}^{3} \cdot \mathrm{m}^{-3} \cdot \mathrm{m}^{-1}=100 \% / 3.2808 \mathrm{ft}$

Not determined.

weast significant difference at the $5 \%$ probability level. effect of fiber content differences of these organic amendments supports the general principal where amendments that increase water availability to plants also result in reduced saturated hydraulic conductivity values.

The maximum pore diameter of a sand-based root zone influences the thickness of the water saturated layer above a water table (Hillel, 2004), referred to as the capillary fringe. Capillary fringe values of unamended and amended sand-based root zones (Table 3 ) show on average a $3-\mathrm{cm}$ increased capillary fringe thickness with amendment by sphagnum and reed-sedge peats. Further, when the literature data accommodated analysis of variance, this effect was shown to be significant, particularly for coarsertextured sand. Pore uniformity indices, where larger values indicate a more uniform pore size distribution (Table 3), show varying results depending on sand particle size distribution. When very uniform sands were used (Bigelow et al., 2004; McCoy and Stehouwer, 1998) native peat amendment decreased pore uniformity, but with less uniform USGAguideline sand (McCoy, 1992; McCoy et al., 2007) pore uniformity was generally increased. Thus, a peatamended root zone when used in the root zone over gravel, USGA construction method can lead to an increased thickness of the capillary fringe (perched water table) above the root zone-gravel interface, and a sharper decline in water contents with increased height above the capillary fringe, making the perching more distinct. Further, this response would be greater for a hemic reedsedge than a fibric sphagnum peat.

A thicker capillary fringe due to peat amendment may result in shallower rooting in sphagnum and reedsedge peat-amended root zones as compared with unamended sand. Thus for experimental USGA putting greens, Murphy et al. (2005) observed root mass densities of $56 \%$ and $59 \%$ of unamended sand for $20 \%$ by volume sphagnum and $10 \%$ by volume reedsedge, respectively at a $22.5-$ to $30-\mathrm{cm}$ depth interval. Root masses averaging $77 \%$ of unamended sand were also observed in the $15.5-$ to $20.5-\mathrm{cm}$ depth interval for $10 \%$ by volume sphagnum-amended root zones by McCoy et al. (2007), although the differences were not significant. These 
rooting differences are likely because of insufficient air-filled porosity deeper within the soil profile, limiting turfgrass rooting. On the other hand, Bigelow et al. (2001b) observed nearly equal rooting at a $20-$ to $30-\mathrm{cm}$ depth interval for unamended sand and sand with $10 \%$ by volume sphagnum.

USGA-guideline sand amended pared with unamended and sphagnumthe water retention curve in the 20to $50-\mathrm{cm}$ soil water suction range (Fig. 2). This is likely because of the with biosolids compost, when comamended sand, shows a flattening of

wide range of particle sizes of the compost amendment including small wood chips used as a bulking agent. Thus, the compost amendment produces a broader pore size distribution than sphagnum, and a thinner capillary fringe (Table 3 ) that would be less distinct within a USGA soil profile. Although rooting data comparing sphagnum peat and compost have not been reported, the water retention behavior would suggest deeper rooting for compost than sphagnum.

Water retention above $\approx 80 \mathrm{~cm}$ of suction is similar for the compost

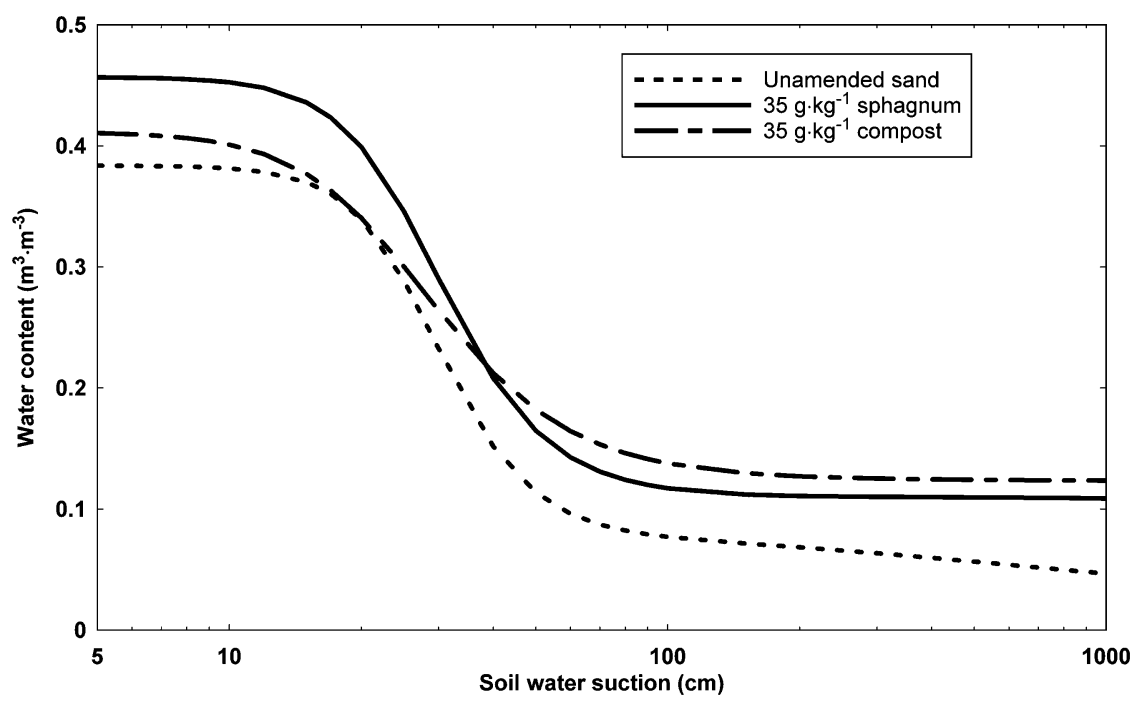

Fig. 2. Water retention curves for unamended U.S. Golf Association (USGA) guideline sand and the sand amended with $35 \mathrm{~g} \cdot \mathrm{kg}^{-1}(3.5 \%)$ sphagnum peat and biosolids compost. The curves are drawn from equations presented in Table 3 of $\operatorname{McCoy}(1992) ; 1 \mathrm{~cm}=0.3937 \mathrm{inch}, 1 \mathrm{~m}^{3} \cdot \mathrm{m}^{-3}=100 \%$.

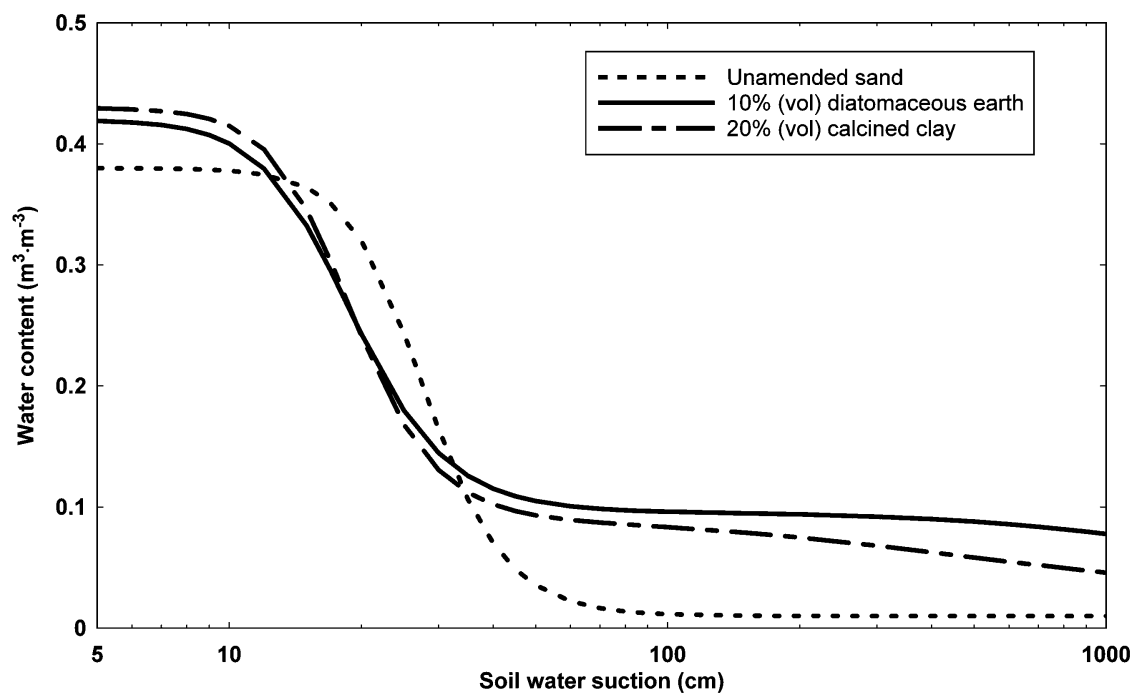

Fig. 3. Water retention curves for unamended medium sand and the sand amended with $10 \%$ by volume diatomaceous earth and $20 \%$ by volume calcined clay. The curves are drawn using Eq. [1] of McCoy and Stehouwer (1998) with parameter values from their Table $5 ; 1 \mathrm{~cm}=0.3937 \mathrm{inch}, 1 \mathrm{~m}^{3} \cdot \mathrm{m}^{-3}=100 \%$. and sphagnum amendments (Fig. 2). This flattening of the curves would suggest limited water release to the turfgrass.

InORGANIC AMENDMENTS. Data from McCoy and Stehouwer (1998) were used to plot water retention curves for unamended, medium sand, and the sand amended with $10 \%$ volume DE and $20 \%$ volume CC (Fig. 3 ). It is important to note that water retention measurements for the construction of these curves used a combination of standard, pressure-plate, and psychrometric methods. This approach was used because pressureplate measurements when used to construct the entire curve fail to extract water held within the internal porosity (Bigelow et al., 2004), resulting in an apparent retention of water within internal pores but without a corresponding release. Yet some degree of plant water release is evident when either a plant bioassay measurement of water extraction (Bigelow et al., 2004) or a psychrometric measurement of water extraction (Curtis and Claassen, 2008; McCoy and Stehouwer, 1998) is used.

In contrast to unamended sand, the DE- and CC-amended curves are displaced upward leading to an overall increased total porosity, and shifted to the left. However, the inorganicamended curves have the same maximum slope as unamended sand. Incorporation of these inorganic amendments resulted in a larger maximum pore diameter, but a similar width of the pore size distribution as compared with unamended sand. This response appears to be because of the greater particle sizes of these inorganic amendments compared with the medium sand of McCoy and Stehouwer (1998). Also, notice that in agreement with Murphy et al. (2005), this response can results in less water retained at $30-\mathrm{cm}$ suction, and smaller CP values for the inorganic-amended root zones than the unamended sand.

Although the inorganic-amended root zones had smaller water contents than unamended sand at $30-\mathrm{cm}$ suction, this was reversed at $40-\mathrm{cm}$ suction (Fig. 3). Also, whereas little water was retained in unamended sand at $60-\mathrm{cm}$ suction the inorganic-amended root zones retained water content values of $0.1 \mathrm{~m}^{3} \cdot \mathrm{m}^{-3}$. Subsequently, for soil water suction values greater 
than $\approx 60 \mathrm{~cm}$, water content of the inorganic-amended sand steadily declined. This would suggest that the DE- and CC-amended root zones are capable of releasing water within this suction range. Thus, the complete water retention curve as opposed to the measurement of a single $\mathrm{CP}$ value demonstrates that these inorganic amendments are capable of retaining and releasing water to plants (Bigelow et al., 2004; Curtis and Claassen, 2008; McCoy and Stehouwer, 1998).

The thickness of the capillary fringe varied with sand texture where inorganic amendment incorporation generally decreased thickness [averaging $3 \mathrm{~cm}$ (mostly due to findings of McCoy and Stehouwer, 1998)] for medium sands but with coarse sand was unchanged for CC and slightly increased for DE (Table 3). The pore uniformity index was unchanged for all inorganic amendment into these uniform, medium-, or coarse-textured sands. Although the influence of inorganic amendments on capillary fringe thickness and pore uniformity resulted from just two studies both using uniformly textured sands, a contrast can be inferred between peat and inorganic amendments when used in a USGA construction. Thus, inorganic amendment incorporation, in contrast to peat, likely leads to a thinner capillary fringe (perched water table) above the root zone-gravel interface, and a less steep decline in water contents with increased height above the capillary fringe, making water perching less distinct. Unlike peat-amended root zones that resulted in shallower rooting, inorganicamended root zones tended to support deeper rooting similar to unamended sand (Bigelow et al., 2001b; Murphy et al., 2005).

\section{Column and field measurement of surface water content}

Organic amendments. Unamended coarse and medium coarse sands, when packed in 12-inch columns to simulate a USGA root zone and drained for $24 \mathrm{~h}$, retained less water in the surface 3 inches than the recommended $0.1 \mathrm{~m}^{3} \cdot \mathrm{m}^{-3}$ value (Bigelow et al., 2004; Waltz et al., 2003). Yet when the coarse sand was amended with $20 \%$ and the medium coarse sand amended by $15 \%$ by volume sphagnum, surface water contents met or exceeded the benchmark value. Further, unamended medium and fine sands had water contents that exceeded $0.1 \mathrm{~m}^{3} \cdot \mathrm{m}^{-3}$ throughout the columns and each 10\% increment increase in sphagnum incorporation, from $0 \%$ to $20 \%$ by volume, resulted in a $0.07 \mathrm{~m}^{3} \cdot \mathrm{m}^{-3}$ increased water content in the surface 3 inches for the medium sand (Bigelow et al., 2004).

Field studies have documented that surface water content increased over time in putting greens built to USGA guidelines where unamended, sand greens had water content values ranging from 0.14 to $0.16 \mathrm{~m}^{3} \cdot \mathrm{m}^{-3}$ and $10 \%$ sphagnum-amended greens had water contents of 0.17 to $0.21 \mathrm{~m}^{3} \cdot \mathrm{m}^{-3}$ (Bigelow et al., 2001b; McCoy et al., 2007; Prettyman and McCoy, 2003). Murphy et al. (2005) observed similar responses for established greens with unamended sand surface water contents of $0.12 \mathrm{~m}^{3} \cdot \mathrm{m}^{-3}$, $10 \%$ reed-sedge-amended water contents of $0.17 \mathrm{~m}^{3} \cdot \mathrm{m}^{-3}$, and $20 \%$ sphagnum-amended water contents of $0.22 \mathrm{~m}^{3} \cdot \mathrm{m}^{-3}$. Among these organic amendment treatments, only the unamended sand green showed lower turfgrass quality.

INORGANIC AMENDMENTS. Medium sand, when packed in 12 -inch columns to simulate a USGA root zone and drained for $24 \mathrm{~h}$, had water contents in the surface 3 inches exceeding $0.1 \mathrm{~m}^{3} \cdot \mathrm{m}^{-3}$. Twenty percent volume incorporation of extruded $\mathrm{DE}, \mathrm{CC}$, and $\mathrm{CZ}$ increased surface water contents up to $\approx 0.04 \mathrm{~m}^{3} \cdot \mathrm{m}^{-3}$, with zeolite only marginally greater than unamended sand and extruded DE yielding the largest increase (Bigelow et al., 2004). On the other hand, medium coarse sand and sand amended with $15 \%$ volume CC and $\mathrm{DE}$, when packed in 12 -inch columns to simulate a USGA root zone and drained for $24 \mathrm{~h}$, failed to achieve water contents in the surface 3 inches exceeding $0.1 \mathrm{~m}^{3} \cdot \mathrm{m}^{-3}$ (Waltz et al., 2003). However, the inorganic amendments did increase surface water content by $\approx 0.03 \mathrm{~m}^{3} \cdot \mathrm{m}^{-3}$ relative to unamended sand, regardless of the amendment source (Waltz et al., 2003).

Following turfgrass establishment, surface water contents in unamended USGA-guideline sand and sand with $10 \%$ volume amendment of $\mathrm{CC}$, sphagnum peat, and $\mathrm{CZ}$ ranged from 0.12 to $0.17 \mathrm{~m}^{3} \cdot \mathrm{m}^{-3}$ with the smallest values for unamended sand and the largest values for sphagnum. Surface water contents for the inorganic amendments were generally intermediate (Bigelow et al., 2001b; Murphy et al., 2005). Bigelow et al. (2001b) observed significantly lower turfgrass quality for only the unamended sand whereas Murphy et al. (2005) observed significantly greater turfgrass quality for the peat-amended root zones but this was when the irrigation system was not turned on until after mid May.

\section{Amendment effects on CEC}

Organic amendments. Carrow et al. (2001) state that for adequate turfgrass performance a putting green root zone need not exceed a CEC value of $\approx 4 \mathrm{cmol}_{\mathrm{c}} \cdot \mathrm{kg}^{-1}$. Assuming USGAguideline sand has a CEC value of $1 \mathrm{cmol}_{\mathrm{c}} \cdot \mathrm{kg}^{-1}$ and that high-quality native peats have CEC values of 120 to $180 \mathrm{cmol}_{\mathrm{c}} \cdot \mathrm{kg}^{-1}$, this would imply by calculation that from 17 to $20 \mathrm{~g} \cdot \mathrm{kg}^{-1}$ of $\mathrm{OM}$ from native peat would be required to achieve a root zone CEC value of $4 \mathrm{cmol}_{\mathrm{c}} \cdot \mathrm{kg}^{-1}$. This is in fairly close agreement with Bigelow et al. (2001a) who measured a CEC value of $4.2 \mathrm{cmol}_{\mathrm{c}} \cdot \mathrm{kg}^{-1}$ for a $20 \%$ sphagnum mix that contained $12 \mathrm{~g} \cdot \mathrm{kg}^{-1}$ $\mathrm{OM}$ and McCoy and Stehouwer (1998) who measured a CEC value of $4.6 \mathrm{cmol}_{\mathrm{c}} \cdot \mathrm{kg}^{-1}$ for sphagnum amendment of $28 \mathrm{~g} \cdot \mathrm{kg}^{-1} \mathrm{OM}$. However, the calculation differs from measurements of Murphy et al. (2005) who found smaller CEC values of 1.4 and $1.9 \mathrm{cmol}_{\mathrm{c}} \cdot \mathrm{kg}^{-1}$ for $20 \%$ volume sphagnum and $10 \%$ volume reed-sedge mixes, respectively. These smaller CEC values were likely because of the smaller OM contents of 9.2 and $7 \mathrm{~g} \cdot \mathrm{kg}^{-1}$ for the $20 \%$ volume sphagnum and $10 \%$ volume reed-sedge. Considering these native peat sources together, it appears that each $10 \mathrm{~g} \cdot \mathrm{kg}^{-1}$ increase in OM of a mix would result in a $2 \mathrm{cmol}_{\mathrm{c}} \cdot \mathrm{kg}^{-1}$ increase in CEC. And from middle values of OM content at $10 \%$ volume increments (as described previously); each $10 \%$ volume addition of sphagnum or reed-sedge would result in a 2 or $4 \mathrm{cmol}_{\mathrm{c}} \cdot \mathrm{kg}^{-1}$ increase in CEC over that of unamended sand.

Compost CEC values are generally lower, ranging from 60 to $120 \mathrm{cmol}_{\mathrm{c}} \cdot \mathrm{kg}^{-1}$. Thus compost addition would need to range from 25 to $50 \mathrm{~g} \cdot \mathrm{kg}^{-1}$ to satisfy the CEC goal. Yet, each $10 \%$ increase in compost of a mix 
is intermediate between sphagnum and reed-sedge in increasing the OM content. Thus one could estimate that each $10 \%$ volume addition of a biosolids or other quality compost would result in an $\approx 3 \mathrm{cmol}_{\mathrm{c}} \cdot \mathrm{kg}^{-1}$ increase in $\mathrm{CEC}$ over that of unamended sand.

INORGANIC AMENDMENTS. Summarizing the results of several studies of sand amended with inorganic amendments, $10 \%$ and $20 \%$ volume incorporation rates of all amendments examined increased the CEC of the unamended sand. For each $10 \%$ increment of the inorganic amendment, the CEC increased from 0.45 to $1.9 \mathrm{cmol}_{\mathrm{c}} \cdot \mathrm{kg}^{-1}$ for CC (Bigelow et al., 200 la, 200lb; McCoy and Stehouwer, 1998; Murphy et al., 2005), from 0.05 to $0.55 \mathrm{cmol}_{\mathrm{c}} \cdot \mathrm{kg}^{-1}$ for DE (Bigelow et al., 2001a; McCoy and Stehouwer, 1998), and from 0.75 to $4.5 \mathrm{cmol}_{\mathrm{c}} \cdot \mathrm{kg}^{-1}$ for CZ (Bigelow et al., 2001a, 2001b). Further, each 10\% increment of added sphagnum increased CEC of the mix from 0.5 to $1.9 \mathrm{cmol}_{\mathrm{c}} \cdot \mathrm{kg}^{-1}$ (Bigelow et al., 2001b; Murphy et al., 2005). Calculating the middle values of these ranges, each 10\% volume addition of $\mathrm{CC}, \mathrm{CZ}$, and DE increased CEC of the mix by approximately $1,2.5$, and $0.3 \mathrm{cmol}_{\mathrm{c}} \cdot \mathrm{kg}^{-1}$, respectively.

Unlike organic amendments, inorganic amendments are selective for monovalent cations on the exchange sites (Bigelow et al., 200la; McCoy and Stehouwer, 1998). This means that inorganic amendments are superior in retaining the nutrient cations potassium $(\mathrm{K})$ and ammonium $\left(\mathrm{NH}_{4}\right)$ than are the organic amendments. Although this aspect has not been fully examined in field applications, there is a significant inverse relationship between inorganic amendment CEC and percentage of $\mathrm{NH}_{4}$ leached from experimental columns (Bigelow et al., 2001a). Thus, even though some inorganic amendments may have smaller CEC values that commonly used organic amendments; their ability to retain important nutrients may equal or exceed that of a native peat.

Finally, the presence of internal porosity, CEC, and preference for monovalent cations found with inorganic amendments has been implicated as resulting in turfgrass salinity stress because of ineffective leaching of soluble salts, particularly sodium (Na). However, batch equilibrium and column leaching experiments have shown this not to be the case (McCoy and Diedrick, 2012).

\section{Amendment effects on water in the capillary fringe}

A USGA soil profile consists of a $30-\mathrm{cm}$ root zone overlying a gravel layer. This layering creates a capillary fringe or perched water above the root zone and gravel interface. Comparing the Darcian flux values for upward water flow from the capillary fringe with near-surface water loss from evapotranspiration (ET) showed that $85 \%$ of the water lost by ET was accounted for by this upward water flux (McCoy and McCoy, 2009). Thus, even though turfgrass rooting is generally concentrated near the upper 1 to 2 inches of the root zone surface, the capillary fringe deep within the root zone is seemingly accessible by the plant. The mechanism for this is the sufficient rates of upward water flow to rehydrate the surface soil layers during the night so that perched water within a USGA green appears to serve reasonably well as a water reservoir for subsequent turfgrass water use. Then, once this perched water is depleted it can be replenished by a recommended, heavy irrigation.

Root zone amendments can have an effect on the rates of upward flow from the capillary fringe to the nearsurface soil layers where most of the rooting resides. This was shown by computer simulation comparing turfgrass water use in a USGA soil profile having root zones of unamended sand, $15 \%$ volume sphagnum, or $15 \%$ volume CC (E.L. McCoy, unpublished data). As expected, the unamended sand root zone showed an early onset of drought stress because of the small $\mathrm{CP}$ values. Unexpectedly, the CCamended root zone delayed the onset of drought stress by $\approx 2 \mathrm{~d}$ compared with sphagnum-amended root zone, even though the sphagnum-amended root zone had larger CP values. The explanation for this is a result of the influence of the amendments on the pore size distribution and the ability of the root zones to conduct capillary fringe water to near the soil surface. As mentioned previously, peat amendments can cause a narrowing of the pore size distribution resulting in fewer water-filled pores capable of conducting capillary fringe water to the surface. The CC amendment, on the other hand, resulted in a broader pore size distribution than peat providing more water-filled pores and a more complete utilization of the capillary fringe. Thus, water availability to the turfgrass within a USGA profile is not completely dictated by root zone CP values, but also by the effect of the amendment in helping modify the paths of capillary water flow and increasing the amount of capillary fringe water conducted to the plant roots.

\section{Longer-term turfgrass quality}

The CP and surface water content targets were established to ensure an adequately moist root zone for improved establishment. How these benchmarks relate to quality of established turfgrass over the longer term has only been examined in one research study conducted in a coolhumid climate at Rutgers University in New Jersey (Murphy, 2007). Over 7 years following establishment in root zones containing $10 \%$ volume incorporation of both organic and inorganic amendments, mean annual turfgrass quality displayed temporal changes and differences among the various amendment treatments (Fig. 4). Notable in these results was the loss of a clear distinction between organic and inorganic amendments following the first year after establishment. Also notable was the fairly consistent improvement in relative visual quality with the inorganic amendments whereas the organic amendments exhibited a decline in the final 2 years of data. Subsequently, in the final year of data, turfgrass quality with inorganic amendments equaled or exceeded that of the organic amendments with the exception of the biosolids compost. These results suggest a disconnect between longer-term turfgrass quality results and $C P$ values of root zone mixes at establishment, where compost, CC, and $\mathrm{CZ}$ at $10 \%$ volume addition had $\mathrm{CP}$ values significantly less than the native, sphagnum, and reed-sedge peats (Murphy et al., 2004, 2005) yet showed similar long-term turfgrass quality. And even though all root zones had CP values greater than the benchmark, the compost, CC, and $\mathrm{CZ}$ root zones at $10 \%$ volume addition had CP values somewhat less than even the unamended sand. Further, a $20 \%$ volume sphagnum treatment located in an enclosed environment had a CP value of $0.28 \mathrm{~m}^{3} \cdot \mathrm{m}^{-3}$ at the 

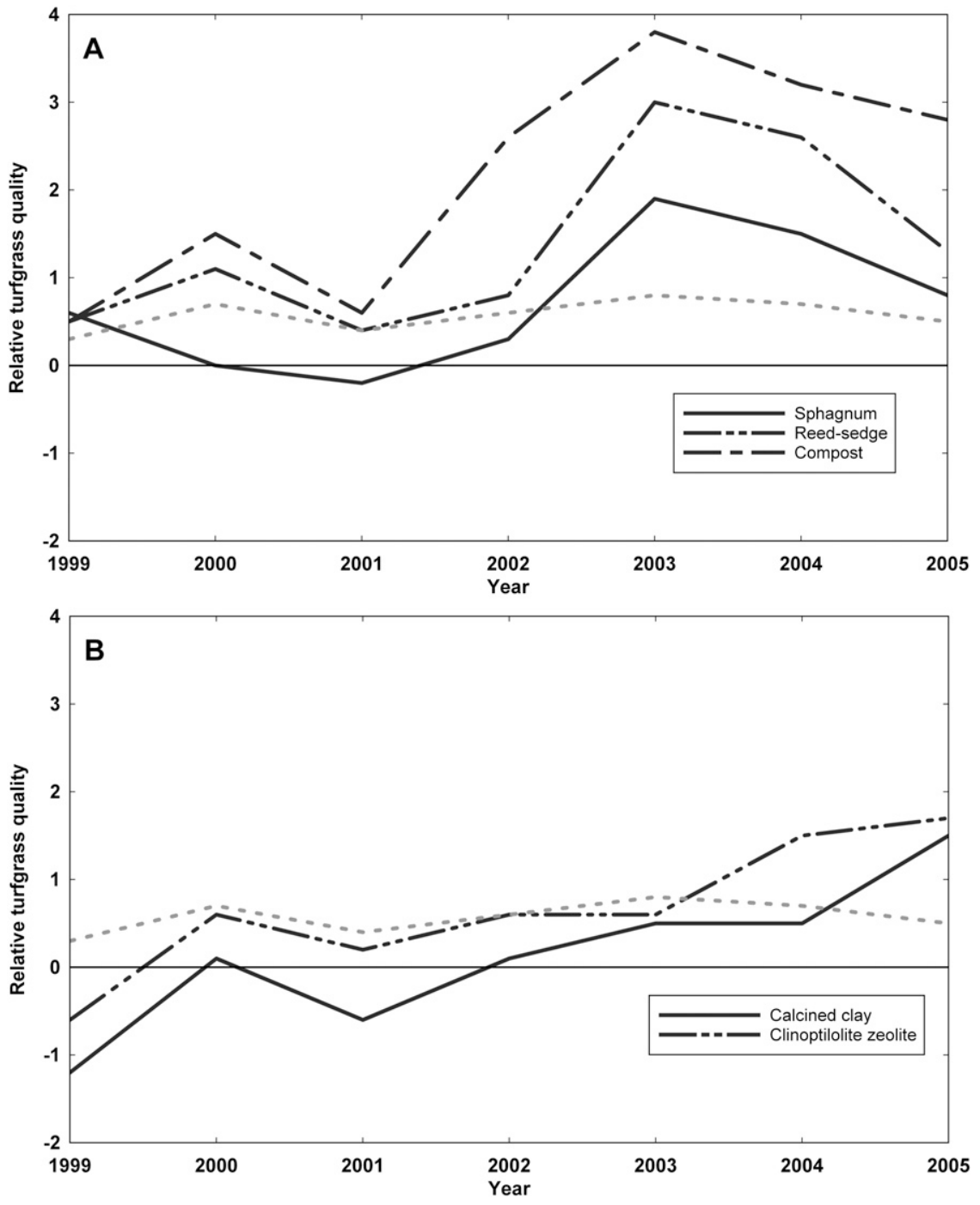

Fig. 4. Turfgrass quality relative to unamended sand (treatment rating minus unamended sand rating) for (A) organic amendments and (B) inorganic amendments all at $10 \%$ by volume. Treatment values exceeding the gray dashed line indicate responses significantly greater than unamended sand. The turfgrass plots were established in 1998. The data are taken from Table 1 of Murphy (2007).

time of establishment, and showed the greatest turfgrass quality during establishment, but suffered a dramatic loss of turfgrass quality 6 years after establishment during hot and humid weather (Devaney et al., 2007). This dramatic decline in quality was attributed to excess surface water retention.

Consequently, the $\mathrm{CP}$ and surface water content benchmarks seemingly relate only to turfgrass establishment and are not as relevant to longer-term turfgrass quality. Indeed, excessive $30-\mathrm{cm}$ CP values can be detrimental over the long-term because of excess surface water retention. At equal volumes of an organic amendment, an inorganic amendment, having a drier root zone, can produce equivalent or superior longer-term quality. Further equal volumes of an inorganic amendment do not necessarily result in an unacceptable droughty root zone when used in a USGA root zone profile. This is because inorganic amendments generally broaden the pore size distribution resulting in deeper rooting and possibly more complete use of the perched water reservoir. Also, inorganic amendments provide a degree of water retention by consistently having greater $40-\mathrm{cm} C P$ values than unamended sand. Finally, whereas organic amendments reduce air-filled porosity values relative to unamended sand, inorganic amendments generally increased air-filled porosity values relative to unamended sand.

\section{Conclusions}

Native peats having OM contents exceeding $750 \mathrm{~g} \cdot \mathrm{kg}^{-1}$ and when incorporated at reasonable rates of $5 \%$ to $20 \%$ by volume served to increase $30-\mathrm{cm} \mathrm{CP}$, root zone surface water contents, and CEC of USGAguideline sands. Further, although there is variability depending on the individual sand, native peat added to a USGA-guideline sand yielding OM content values of $\approx 15 \mathrm{~g} \cdot \mathrm{kg}^{-1}$ would typically yield benchmark values of $\mathrm{CP}=0.2 \mathrm{~m}^{3} \cdot \mathrm{m}^{-3}$, surface water content $=0.1 \mathrm{~m}^{3} \cdot \mathrm{m}^{-3}$, and CEC values between 3 and $4 \mathrm{cmol}_{\mathrm{c}} \cdot \mathrm{kg}^{-1}$. This OM content would be roughly equivalent to a $15 \%$ volume incorporation of a fibric sphagnum or $7.5 \%$ volume of a hemic reed-sedge. At the same time, it may be difficult to accurately and consistently blend amendments at lower rates ( $5 \%$ to $10 \%$ by volume). Thus, less fibrous, hemic organic amendments can result in dangerously low air-filled porosity and Ks values when blending errors result in excessive OM contents, making fibric peats preferable.

Incorporating these same rates of an inorganic amendment or biosolids compost often resulted in $30-\mathrm{cm}$ CP values less than or equal to USGAguideline sand even though surface water contents and CEC values, except for DE, were greater than unamended sand. Further a 15\% volume rate of an inorganic amendment would likely result in CP and surface water content values less than the benchmark values, and CEC values between 1.5 (for CC) and 4 (for CZ) $\mathrm{cmol}_{\mathrm{c}} \cdot \mathrm{kg}^{-1}$. The inorganic amendments show an interesting dichotomy in that $\mathrm{DE}$ materials provide a much greater contribution to water retention than $\mathrm{CZ}$; whereas $\mathrm{CZ}$ materials provide a much greater nutrient retention contribution than DE. Calcined clay materials are generally intermediate on both measures. Also, CC was the only inorganic amendment that did not generally yield reduced Ks values compared with unamended sand. This is likely because of the very uniform particle sizes of the CC amendment studied.

The CP benchmark measured at $30 \mathrm{~cm}$ of soil water suction should be questioned in that it may bias against the use of biosolids compost and inorganic amendments that shift the pore size distribution to larger diameter 
pores, reduce the thickness of the capillary fringe, and can create a broader pore size distribution. These features of water retention in root zones should contribute to deeper rooting than for peat amendment and an improved capability of turfgrass water uptake from the capillary fringe. Further, there was a disconnect between longer-term turfgrass quality and $30-\mathrm{cm}$ CP values of the original root zone mix. Measurement of $\mathrm{CP}$ at $40-\mathrm{cm}$ suction would be a better indication of water retention in sand-based root zones for all amendment types.

Lastly, inorganic amendments were observed to produce a drier root zone that may be preferred for both playability and long-term agronomic concerns. From comparisons between inorganic amendments it seems that a CC product, sized to closely match USGA sand size specifications (Table 2) such as Profile, may be the most suited because of its uniform particle size distribution, and balanced water and nutrient retention properties.

\section{Literature cited}

Bigelow, C.A., D.C. Bowman, and D.K. Cassel. 2001a. Nitrogen leaching in sandbased rootzones amended with inorganic soil amendments and sphagnum peat. J. Amer. Soc. Hort. Sci. 126:151-156.

Bigelow, C.A., D.C. Bowman, D.K. Cassel, and T.W. Rufty, Jr. 2001b. Creeping bentgrass response to inorganic soil amendments and mechanically induced subsurface drainage and aeration. Crop Sci. 41:797-805.

Bigelow, C.A., D.C. Bowman, and D.K. Cassel. 2004. Physical properties of three sand size classes amended with inorganic materials or sphagnum peat moss for putting green rootzones. Crop Sci. 44: 900-907.

Brockhoff, S.R., N.E. Christians, R.J. Killorn, R. Horton, and D.D. Davis. 2010. Physical and mineral-nutrition properties of sand-based turfgrass root zones amended with biochar. Agron. J. 102: 1627-1631.

Carlson, M.S., C.L. Kerkman, and W.R. Kussow. 1998. Peats and supplements for root zone mixes. Golf Course Mgt. 66(9):70-74.

Carrow, R.N., D.V. Waddington, and P.E. Rieke. 2001. Turfgrass soil fertility and chemical problems: Assessment and management. Ann Arbor Press, Chelsea, MI.
Cook, A. and S.W. Baker. 1998. Effects of organic amendments on selected physical and chemical properties of rootzones for golf greens. J. Turfgrass Sci. 74:2-10.

Curtis, M.J. and V.P. Claassen. 2008. An alternative method for measuring plant available water in inorganic amendments. Crop Sci. 48:2447-2452.

Devaney, J., J.A. Murphy, H. Samaranayake, T.J. Lawson, and D. Gimenez. 2007. Maturation of amended sand root zones. Proc. 16th Annu. Rutgers Turfgrass Conf. $16: 20,21$.

Davis, W.B., J.L. Paul, J.H. Madison, and L.Y. George. 1970. A guide to evaluating sands and amendments used for high trafficked turfgrass. Agr. Ext. Serv., Univ. California, CA.

Githinji, L.J., Dane, and R. Walker. 2006. Physical and hydraulic properties of rootzone inorganic amendments for turf putting green. Amer. Soc. Agron., Crop Sci. Soc. Amer., Soil Sci. Soc. Amer. p. 15 (abstr.).

Hillel, D. 2004. Introduction to environmental soil physics. Academic Press, San Diego, CA.

McCoy, E.L. 1992. Quantitative physical assessment of organic materials used in sports turf rootzone mixes. Agron. J. 84: 375-381.

McCoy, E.L. 1998. Sand and organic amendment influences on soil physical properties related to turf establishment. Agron. J. 90:411-419.

McCoy, E.L. and K. Diedrick. 2012. Dissolved salts in root zones containing inorganic amendments. Golfdom 68(3): 41-44.

McCoy, E.L., P. Kunkel, G.W. Prettyman, and K.R. McCoy. 2007. Root zone composition effects on putting green soil water. Appl. Turfgrass Sci. doi:10.1094/ ATS-2007-1119-02-RS.

McCoy, E.L. and K.R. McCoy. 2009. Simulation of putting-green soil water dynamics: Implications for turfgrass water use. Agr. Water Mgt. 96:405-414.

McCoy, E.L. and R.C. Stehouwer. 1998. Water and nutrient retention properties of internally porous inorganic amendments in high sand content root zones. J. Turfgrass Mgt. 2:49-69.

McGeary, R.K. 1961. Mechanical packing of spherical particles. J. Amer. Ceram. Soc. 44:513-522.

Muehlbach, A., D. Karcher, and M. Richardson. 2007. Water retention of sand-based rootzones with organic and inorganic amendments. Golf Course Mgt. 75(2):138-142.
Murphy, J.A. 2007. Rootzone amendments for putting green construction. USGA Green Section Record. 45(3):813 .

Murphy, J.A., J.A. Honig, H. Samaranayake, T.J. Lawson, and S.L. Murphy. 2001. Creeping bentgrass establishment on root zones varying in sand sizes. Intl. Turfgrass Soc. Res. J. 9:573-579.

Murphy, J.A., H. Samaranayake, J.A. Honig, T.J. Lawson, and S.L. Murphy. 2004. Creeping bentgrass establishment on sand-based rootzones varying in amendment. USGA Turfgrass Environ. Res. 3(10):1-15.

Murphy, J.A., H. Samaranayake, J.A. Honig, T.J. Lawson, and S.L. Murphy. 2005. Creeping bentgrass establishment on amended-sand root zones in two microenvironments. Crop Sci. 45:15111520 .

Prettyman, G.W. and E.L. McCoy. 2003. Profile layering, root zone permeability, and slope affect on soil water content during putting green drainage. Crop Sci. 43:985-994.

Taylor, D.H. and G.R. Blake. 1984. Predicting sand content of modified soil mixtures from sand, soil, and peat properties. Agron. J. 76:583-587.

Taylor, D.H., C.F. Williams, and S.D. Nelson. 1997. Water retention in rootzone soil mixtures of layered profiles used for sports turf. HortScience 32:82-85.

Thorpe, V.A. 1973. Collaborative study of the cation exchange capacity of peat materials. J. Assn. Anal. Chem. 56:154157.

U.S. Department of Agriculture. 1954. Diagnosis and improvement of saline and alkali soils. U.S. Dept. Agr. Hdbk. 60, Washington, D.C.

Van Genuchten, M.Th. 1980. A closedform equation for predicting the hydraulic conductivity of unsaturated soils. Soil Sci. Soc. Amer. J. 44:892-898.

Waddington, D.V., T.L. Zimmerman, G.J. Shoop, L.T. Kardos, and J.M. Duich. 1974. Soil modification for turfgrass areas. I. Physical properties of physically amended soils. Pennsylvania State Univ. Agr. Expt. Sta. Prog. Rpt. 337.

Waltz, F.C., Jr., V.L. Quisenberry, and L.B. McCarty. 2003. Physical and hydraulic properties of rootzone mixes amended with inorganics for golf putting greens. Agron. J. 95:395-404.

Zhang, J. and S.W. Baker. 1999. Sand characteristics and their influence on the physical properties of rootzone mixes used for sports turf. J. Turfgrass Sci. 75:66-73. 